\title{
ACTUAL CONCEPT OF OSTEOPOROSIS IN PARAPLEGIA
}

\author{
By Alex Chantraine \\ Division of Physical Medicine and Rehabilitation, Hôpital Cantonal-Beau-Séjour, \\ University of Geneva, I2I I Switzerland
}

Abstract. The osteoporosis which appears in paraplegics below the neurological lesion has been studied in IOO patients with the following parameters: quantitative X-rays, urinary hydroxyproline excretion, kinetic study of calcium metabolism by ${ }^{45} \mathrm{Ca}$, serum phosphorus and calcium, parathormone and calcitonin radio-immunoassay, quantitative histology, density fractionation of bone and amino-acid composition of fractionated bone analysis.

All our results show that the important bone resorption occurring very early in the paraplegia is immediately followed by an increase of the bone repair. This osteoporosis below the neurological lesion in paraplegia represents an unbalance between the synthesis and the resorption of bone which possesses a large degree of activity. Furthermore, we demonstrated that the collagen of this bone is underhydroxylated. Following the quantitative X-rays and intraosseous phlebography results we have considered the aetiopathogenesis of this osteoporosis. It seems that vascular modifications due to the lesion of the autonomic nervous system play an important role and furthermore we believe that immobilisation represents only a minor factor in the aetiology of this osteoporosis.

IN paraplegia an osteoporosis appears very early after the spinal cord lesion and is located below this lesion.

The aetiopathogenesis of this osteoporosis is not known although the disuse factor has been advanced. On the other hand, the angiographic investigations made by Galibert (1959) and Rossier et al. (1973) have shown that modifications existed below the spinal lesion since the beginning of the paraplegia. Benassy et al. (1963) reported changes in the arterial and venous blood gases $\left(\mathrm{O}_{2}\right.$ saturation, $\left.p \mathrm{H}, p \mathrm{CO}_{2}, p \mathrm{O}_{2}\right)$ consisting in a marked arterialisation of lower limb venous blood. Thus, these modifications evolve in the same direction as the angiographic ones. These blood flow modifications could play a role in the pathogenesis of this porosis. Vasomotor paralysis, a consequence of the orthosympathic system damage, provokes a slowdown of the intraosseous circulation. Arterio-venous shunts also give an increase of the venous pressure. This situation leads to an increase of the intraosseous medullary pressure. Trueta (I964, I968) and Dhem (1973) have shown the consequence of intraosseous circulation decrease on the cellular differentiation.

Stimulated by these data and the fact that the autonomic nervous system (ANS) might play a role in this osteoporosis, we have reviewed the problem and investigated the following parameters: X-rays; intramedullary pressure of bone; urinary hydroxyproline excretion; kinetic study of calcium metabolism by ${ }^{45} \mathrm{Ca}$; urine calcium; serum calcium and phosphorus; serum calcitonin and parathormone; quantitative histological study; density fractionation of bone and amino-acid composition of fractionated bone analysis.

We will briefly summarise the methods and the results of those investigations which have been reported elsewhere. 


\section{Clinical Aspect}

A group of 100 paraplegics underwent standard X-rays which showed signs of osteoporosis below the neurological lesion in 88 per cent. Furthermore, 80 per cent of patients presented it in the first 6 months of their paraplegia. A quantitative X-rays study using Virtama and Helela (I969) and Dequeker (I972) parameters has also been realised. It consisted in measurements of the outer $(D)$ and inner $(d)$ diameter of the second metacarpal and femur. The cortical thickness $(D-d)$ was also measured. Compared to a series of normal subjects we have found that in paraplegics $D$ and $d$ were significantly increased as far as the femur is concerned (Chantraine et al., 1976a). The increase of the periosteal and endosteal diameter was characterised by the speed with which it appears. We observed an enlargement of $D$ of 2 to $4 \mathrm{~mm}$ in a few months, which is similar to many experimental and clinical studies reported in the literature on the effect of arterio-venous fistula. The Klippel-Trenaunay syndrome is one example of an increase of the width and length of bone in subjects where arterio-venous fistula with circulation modification and venous stasis exist (Malan \& Puglionisi, 1964). Furthermore, the cortical thickness of the femur was slightly decreased in paraplegia. The intramedullary pressure of the femur in the same patients has been recently controlled and we found it increased (Chantraine et al., 1968) in paraplegics, in general, to two to three times the normal rate.

\section{Biological Aspect}

In paraplegia, kinetic studies of calcium metabolism by ${ }^{45} \mathrm{Ca}$ as well as urinary excretion of hydroxyproline have been reported previously (Chantraine, I97I).

In those patients, blood tests showed no gross modification except for phosphoraemia which is very high at the beginning and decreases in a few months (Fig. I). We have studied in paraplegia serum Parathormone (PTH) and Calcitonin (CT) (Heynen et al., I978) and it showed evidence of a decrease of the PTH associated with an increase or normal rate of CT. The CT has a tendency to decrease with the evolution. In a quantitative histological study we have shown that bone resorption reached its maximum after 3 to 5 months following the neurological lesion (Chantraine et al., I974).

\section{Density Fractionation}

Bone particles as any calcified tissues can be fractionated according to the degree of mineralisation of the extracellular matrix, a time-dependent maturation process (Richelle, 1967). The principle of such a fraction procedure has been reported elsewhere (Nusgens et al., 1972). The fractionation pattern depends on the rate of growth and/or remodelling of the bone samples. Mineralisation is related to the maturation of the newly formed matrix, a process independent of ageing.

Figure 2 shows the distribution pattern of particles. One can see that in paraplegia whatever the bone below the lesion is, as compared to normal similarly adult bone, there is an increased proportion of fraction 2 of non-completely mineralised osteons. Normal adult bone is characterised by a large proportion of fraction 3 . 


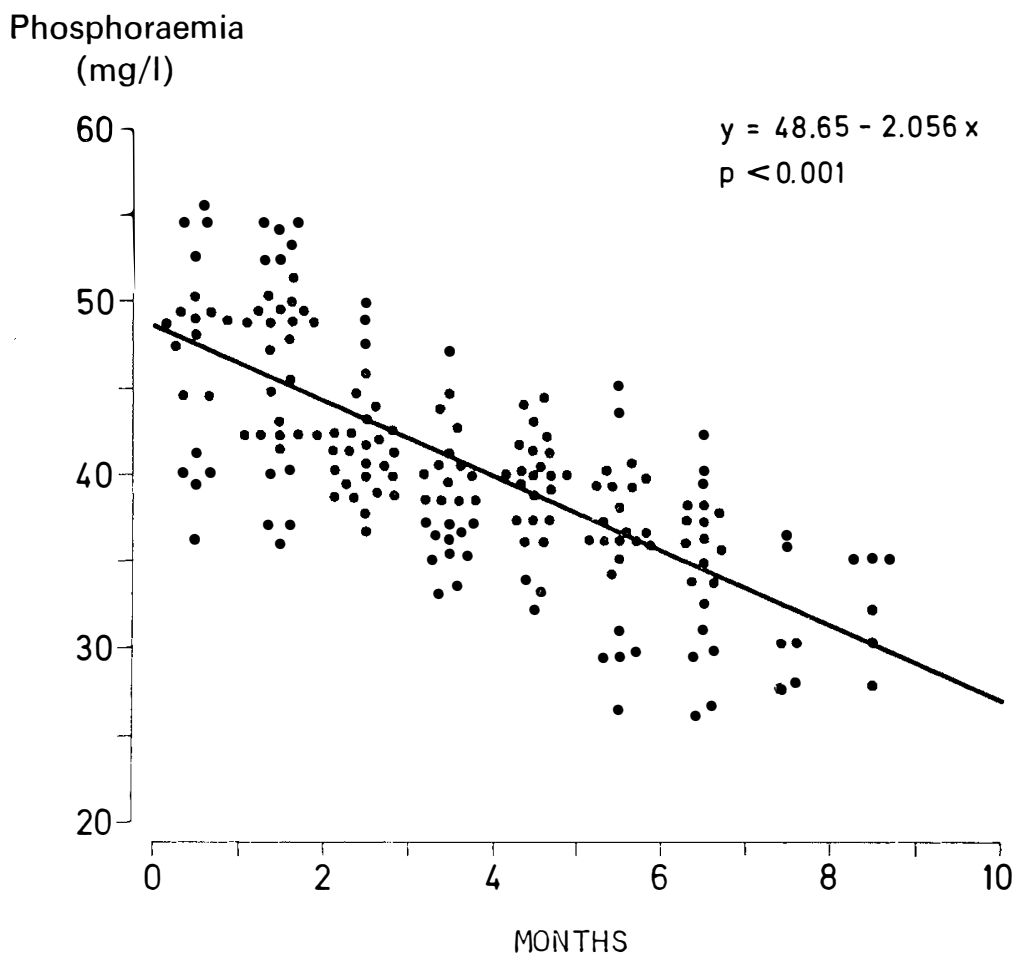

FIG. I

The diagram shows the elevate phosphoraemia as soon after the paraplegia (time 0 ) with the progressive decrease in the course of the evolution.

\section{Amino-acid Composition}

The maturation of the protein matrix during calcification is accompanied by a progressive change in its overall amino-acid composition. When comparing the least mineralised fraction with fractions of progressively increasing specific gravity, it is quite obvious that the proportion of collagen in the protein matrix increases progressively. The concentration of hydroxyproline and hydroxylysine reaches almost the proportion which is found for these collagen-specific hydroxylated amino acids in the purified collagen isolated from various connective tissues including bone. Other amino acids such as glycine, alanine and proline which are present at high concentration in collagen, also increase progressively with the mineralisation of the matrix. All the other amino acids and mainly aspartic and glutamic acids, leucine and half-cystine are progressively reduced. Assuming that all the hydroxyproline residues are contained in collagen and knowing the aminoacid composition of this protein, it is possible to estimate by calculation, in all bone fractions, the proportion of the non-collagen polypeptide moiety and its amino-acid composition (Nusgens et al., I972).

There exists similarities in amino-acid composition between the various density fraction of bone in the normal subjects and in the paraplegic patients, except for the hydroxyproline. The hydroxylation of proline in collagen was determined from amino-acids analysis, performed on the most mineralised fraction and compared to similar fractions of control. We observed a ro per cent decrease 


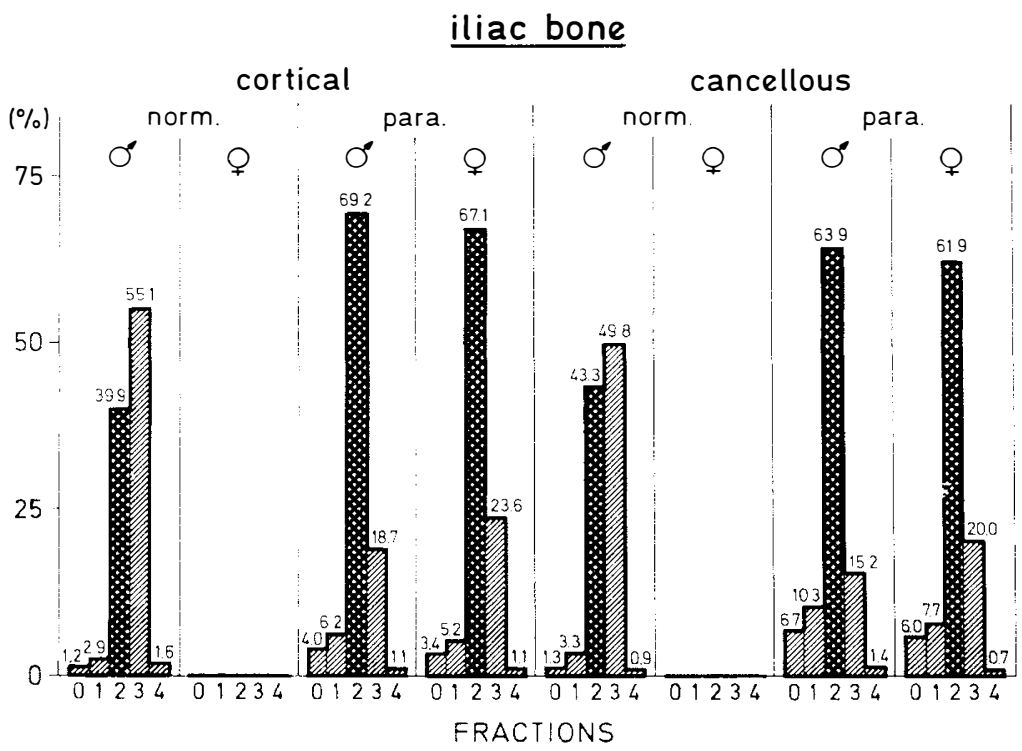

FIG. 2

The bone particles distribution profile shows in normal subject a larger proportion of the fraction 3. Whereas in paraplegia (in the first year after the lesion) fraction 2 is the most abundant.

TABLE I

\begin{tabular}{|c|c|c|c|c|c|c|}
\hline & \multicolumn{3}{|c|}{ Fraction 2} & \multicolumn{3}{|c|}{ Fraction 3} \\
\hline & Norm. (7) & Para. (4) & POA (4) & Norm. (6) & Para. (8) & $\mathrm{POA}(5)$ \\
\hline $\mathrm{OH}$ proline & 89 & $78^{\star \star}$ & $84^{\star}$ & 93 & $83^{\star \star}$ & $84^{\star \star}$ \\
\hline Proline & II 2 & $\operatorname{II} 7^{\star}$ & II $8^{\star}$ & II6 & II9 & 120 \\
\hline $\mathrm{OH}$ lysine & $3 \cdot 5$ & $2 \cdot 9$ & $3 \cdot 8$ & $3 \cdot 8$ & $3 \cdot 9$ & $4^{\cdot 0}$ \\
\hline Lysine & 32 & $35^{\star}$ & 30 & 30 & $3 \mathrm{I}$ & 28 \\
\hline Glycine & 302 & 283 & 305 & 315 & 3I I & 316 \\
\hline Glutamic & 80 & 79 & 78 & 77 & 78 & 78 \\
\hline Leucine & $3 I$ & $40^{\star}$ & 33 & 29 & $3 I$ & $3 I$ \\
\hline \multirow{2}{*}{$\begin{array}{l}\% \text { hydroxylation } \\
\text { proline } \\
\% \text { hydroxylation } \\
\text { lysine }\end{array}$} & $44 \cdot 4$ & $40 \cdot 0^{\star \star}$ & $4 \mathrm{I} \cdot 5^{\star \star}$ & $44^{\cdot 2}$ & $4 \mathrm{I} \cdot 0^{\star \star}$ & $4 \mathrm{I} \cdot 2^{\star \star}$ \\
\hline & $9 \cdot 8$ & $7 \cdot 6$ & II $\cdot 2$ & II $\cdot 2$ & II $\cdot 2$ & $12 \cdot 5$ \\
\hline
\end{tabular}

in the hydroxylation of collagen in these calcified tissues (Table I) (Chantraine et al., 1976b).

\section{Discussion}

The neural and vascular factors may be important determinants of increased bone resorption in paraplegia. The modifications of the circulation below the spinal cord lesion seem to play a role since it has been pointed out the presence 
of arterio-venous shunts in those patients (Galibert, I959; Rossier et al., 1973) as well as the blood gases changes (Benassy et al., 1963). The vasomotor paralysis leads to a decrease of the bone blood flow and finally to a venous stasis accompanied by a tissue acidosis. We have confirmed the hypothesis of an intraosseous venous stasis below the neurological level, demonstrating the increased intramedullary pressure in the femur. Such a disturbance might have an influence on the cellular bone differentiation as mentioned by Dhem (1973) and Andrews and Bassett (1971).

A striking observation has been pointed out with the significant increase of the outer and the inner diameters of the femur a few months following paraplegia. This seems to look like the Klippel-Trenaunay syndrome characterised by an increase of the length of the long bones and where an important apposition of periosteal surfaces and resorption of endosteal surfaces is observed (Malan \& Puglionisi, 1964), due to the presence of arterio-venous shunt and deep angioma. Since vascular troubles, due to the ANS alteration exist and, furthermore, that arterio-venous shunts are found in paraplegia, one can think that the similar pathological mechanisms lead to these syndromes. Furthermore, standard X-rays as well as quantitative histological study demonstrate that bone resorption in paraplegia appears very early after the lesion (Minaire et al., I974; Chantraine et al., I974, 1976a). We also demonstrated that this resorption is not parathyroid dependent. On the contrary, we have experiences which conform with the criteria given by Franchimont and Heynen (1974) about the sideration of the parathyroid function. The bone resorption below the spinal lesion seems to be a primary phenomena, associated with a local metabolic alteration which causes changes of the phosphocalcic metabolism. These changes influence, then, the PTH and CT secretions as we have observed (Heynen et al., 1978). The reduction of the PTH secretion and the increased or normal CT level should modify the properties of the bone cells. According to Rasmussen and Bordier (I973), the sideration of the parathyroid function, although the $\mathrm{C}$ cells function remain normal, might diminish the resorption activity of the osteoclasts and accelerate the differentiation of osteoclasts into osteoblasts. The osteoblastic activation should permit the repair of the bone resorption.

However, the vascular problems do not explain everything. The chemical bone composition that we have analysed shows that there exists a collagen synthesis anomaly in the paraplegic bone fractions. With Lapiere and Nusgens, we demonstrated a lack of proline hydroxylation in hydroxyproline, probably due to a defect of the prolyl-hydroxylase activity producing an abundant proportion of underhydroxylated collagen (Chantraine et al., 1976b). On the other hand, we know that thermic stability of underhydroxylated collagen is less than normal hydroxylated collagen (Rosenbloom et al., I973). In these patients, the urinary hydroxyproline excretion is also largely increased and might represent the catabolism of such hydroxylated collagen. Figure 3 represents a diagram of our conception of the osteoporosis pathogenesis in paraplegia.

The high degree of turnover previously demonstrated by kinetic analysis with ${ }^{45} \mathrm{Ca}$ showing an increase of the different parameters (Chantraine, I97I) is confirmed by the present work. Quantitative X-rays study, distribution pattern of fractionated bone and amino-acid analysis concur to show that bone, below the neurological lesion in paraplegic patients, possesses a high turnover and represents newly formed bone. In conclusion, we can add that many of the old myths concerning the mechanisms of osteoporosis have been exploded in recent years and it becomes necessary to reconsider the mechanisms by which osteoporosis appears. 


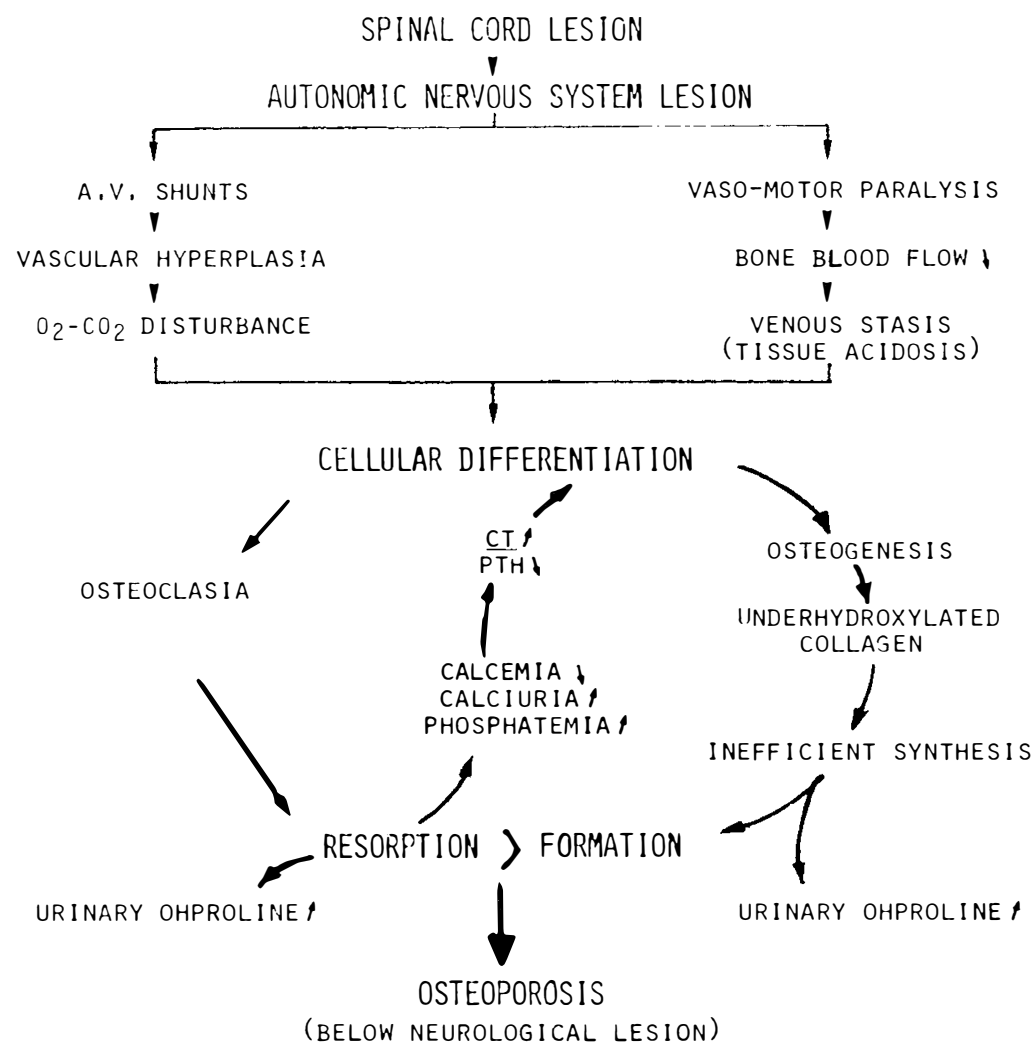

FIG. 3

Schema of our pathogenic concept of osteoporosis in paraplegia.

Furthermore, the osteoporosis that rapidly develops following paraplegia, usually called 'immobilisation osteoporosis', does not result from failure of muscle tension to stimulate bone formation since we demonstrated the high degree of turnover found in paraplegic bone as Heaney (1962) also mentioned. Finally, osteoporosis in paraplegia represents an imbalance between the synthesis and the resorption of bone which possesses a large degree of activity, where neural and vascular factors display an important role which leads to cellular reaction.

\section{RÉSUMÉ}

L'ostéoporose, qui apparaît sous la lésion médullaire chez le paraplégique, a été étudiée chez roo patients depuis le début de l'affection. Au cours de ce travail, les paramètres suivants ont été étudiés: radiographie quantitative, excrétion urinaire de l'hydroxyproline, étude cinétique du métabolisme calcique par le ${ }^{45} \mathrm{Ca}$, phosphore et calcium sérique, calcitonine et parathormone sérique, histologie quantitative, fractionnement de l'os suivant un gradient de densité et analyse de la composition en acides aminés de ces fractions osseuses.

Tous les résultats de cette étude montrent que l'importante résorption de l'os souslésionnel, survenant dès le début de la paraplégie, est immédiatement suivie d'un accroissement de la réparation osseuse. Cette ostéoporose sous-lésionnelle est liée a un déséquilibre entre la synthèse et la dégradation d'un os dont l'activité métabolique est importante. Par ailleurs, il existe un défaut dans la synthèse du collagène de l'os du paraplégique sous 
forme d'une diminution de l'hydroxylation de la proline. En outre, les résultats de la radiographie quantitative ainsi que des phlébographies intra-osseuses nous ont fait considérer l'étiopathogénie de cette ostéoporose. Il semble bien que les modifications vasculaires, dues à la lésion du système neuro-végétatif, y jouent un rôle important et que le facteur 'immobilisation' ne doive plus être retenu que comme élément mineur.

\section{ZUSAMMENFASSUNG}

Die beim Paraplegiker im Lähmungsbereich auftretende Osteoporose wurde bei roo Patienten seit Beginn des neurologischen Ausfalls verfolgt. Die folgenden Parameter wurden untersucht: quantitative Radiographie, Hydroxyprolin-ausscheidung im Urin; Kalziumkinetik ${ }^{45} \mathrm{Ca}$; Blutspiegel von Phosphor, Kalzium, Kalzitonin und Parathormon; quantitative Histologie; Fraktionierung des Knochens nach verschiedenen Härtegraden und jeweilige Bestimmung des Aminosäurengehaltes.

Sämtliche Resultate dieser Untersuchung weisen daraufhin, dass die starke und von Beginn der Lähmung einsetzende Resorption gleichzeitig von einem verstärkten Wiederaufbau begleitet wird. Die Osteoporose in Lähmungsbereich ist somit auf eine Störung im Gleichgewicht zwischen Knochenaufbau und- abbau zurückzuführen. Der Knochenmetabolismus ist deutlich verstärkt. Andererseits ist beim Paraplegiker die Kollagensynthese im Sinne einer verminderten Hydroxylation des Prolins gestört. In Anschluss an die Resultate der quantitativen Radiographie und Knochenphlebographie wird die mögliche Aetiopathogenese der Osteoporose erläutert. Vaskuläre, auf Störungen im neurovegetativen System zurückzuführende Veränderungen scheinen eine wichtige Rolle zu spielen; dagegen scheint der Faktor 'Immobilisation' nur noch geringe Bedeutung zu haben.

\section{REFERENCES}

Andrew, C. \& BAsset, L. (197I). Biophysical Principles affecting Bone Structure: Volume 3. Academic Press, New York, p. 584.

Benassy, J., Mazabraud, J. \& Diverres, J. C. (I963). L'ostéogénèse neurogène. Rev. Chir. Orthop., 49, 95-I I6.

Chantraine, A. (I97I). Clinical investigations of bone metabolism in spinal cord lesions. Paraplegia, 8, 253-259.

Chantraine, A., Chapard, R. \& Leroux, G. (I976a). Étude radiologique de la masse osseuse chez le paraplégique. Comptes rendus du ier Symposium CEMO. Méd. et Hyg. Genève, 44-52.

Chantraine, A., Nusgens, B. \& Lapiere, Ch. M. (I976b). Underhydroxylated collagen in bone of patients with spinal cord lesion. Vme meeting, European Fed. of the Connective Tissue Clubs, Liège, 31-32.

Chantraine, A., Hacher, H. J. \& Schinas, P. (I978). Étude de la pression intra-médullaire de l'os chez le paraplégique. Premiers enseignements. To be published.

Chantraine, A., Meunier, P., Minaire, P., Edouard, C., Bernard, J. \& Delvigne, M. A. (1974). Étude histologique quantitative de l'os du paraplégique. F. Belge Rhum. Méd. Phys. 29, I74-195.

Dequeker, J. (1972). Bone Loss in Normal and Pathological Conditions. Leuven Univ. Press, pp. I-2I 4 .

Dhem, A. (1973). Les mécanismes de destruction du tissu osseux. Acta Orthop. Belg. 39, 423-433.

Franchimont, P. \& Heynen, G. (1976). Parathormone and Calcitonin Radioimmunoassay in Various Medical and Osteoarticular Disorders. Masson. Inc., pp. I-I3I.

GALIBERT, P. (I959). Remarques à propos du syndrome neuro-végétatif des traumatismes de la moelle épinière. Neurochir. 5, 355-359.

Heaney, R. P. (1962). Radiocalcium metabolism in disuse osteoporosis in man. Amer. F. Med. 33, $\mathrm{r} 88-200$.

Heynen, G., Chantraine, A. \& Franchimont, P. (1978). Metabolic study in spinal cord injuries. To be published.

Malan, E. \& Puglionisi, A. (I964). Congenital angiodysplasias of the extremities (note I: generalities and classification venous dysplasias). F. Cardiovasc. Surg. 5, 87-130.

Minaire, P., Meunier, P., Edouard, C., Bernard, J., Courpron, P. \& Bourret, J. (I974). Quantitative histological data on disuse osteoporosis. Calcif. Tissue Res. 17, 57-73. 
Nusgens, B., Chantraine, A. \& Lapiere, Ch. M. (1972). The protein in the matrix of bone. Clin. Orthop. and Related Research, 88, 25I-274.

Rasmussen, H. \& Bordier, Ph. (I973). The cellular basis of metabolic bone disease. New England F. Med. 289, 25-32.

RiChelle, L. J. (I967). Contribution à l'étude du métabolisme minéral de l'os chez le rat. Thèse, Univ. Liège, I6r.

Rosenbloom, J., Harsch, M. \& Jimenez, S. (I973). Hydroxyproline content determines the denaturation temperature of chick tendon collagen. Arch. Biochem. Biophys. I56, 478 .

Rossier, A. B. et al. (I973). Current facts on para-osteo-arthropathy (POA). Paraplegia, II, 36-78.

Trueta, J. (1964). The dynamics of bone circulation. In Bone Dynamics, ed. H. M. Frost. Little, Brown and Co, Boston, pp. 245-258.

Trueta, J. (1968). Studies of the Development and Decay of the Human Frame. Heinemann, London.

VirTAMA, P. \& Helela, T. (I969). Radiographic measurements of cortical bone: variations in a normal population between I and 90 years of age. Acta Radiolog., Suppl., 293. 